\title{
Internationalisation of a teaching experience: ToSCA UPC education for innovation workshop at UFPS, Colombia
}

\author{
Adroer Puig, Marta ${ }^{\text {a }}$; Carmen Xiomara Díaz Fuentes ${ }^{\text {b }}$ Zamora i Mestre, Joan Lluís ${ }^{\text {c }}$ \\ ${ }^{a}$ Department of Architectural Technology, Universitat Politècnica de Catalunya, Spain, \\ ${ }^{\mathrm{d}}$ Department of Architecture, Universidad Francisco de Paula Santander, Colombia, \\ ${ }^{c}$ Department of Architectural Technology, Universitat Politècnica de Catalunya, Spain.
}

\begin{abstract}
ToSCA is an optional and intensive technical product innovation workshop that aims to include education for innovation of constructive solutions in the grade architecture programme, by applying a didactic structure based on problem solving skills, combined with cooperative learning structures and involving an industry of the sector every edition a client. The workshop has been held annually at the Vallès School of Architecture, Universitat Politècnica de Catalunya, since 2007 and the results of each edition can be found at:

http://www.etsav.upc.edu/assignatures/tosca.

After eleven editions of ToSCA_ETSAV and one edition in TUM Munich, with a very good outcomes and by the invitation of the School of Architecture of the Francisco de Paula Santander University in Cúcuta, Colombia, we assumed, between both institutions, the challenge of internationalizing the ToSCA experience, to carry out within the Deepening Course "the ceramics in the architectural project", a first educational workshop for the innovation of technical product, suggesting the adaptability of the ToSCA methodology, in a different socio-cultural environment.
\end{abstract}

Keywords: Internationalization, innovation, building technologies, education, workshop. 


\section{Introduction}

ToSCA is an optative and intensive week workshop on Technical Product Design Innovation (PDI), that was born in January 2007 under Dr J. LL Zamora direction and a team of UPC Department of Technology's lecturers, that wanted to achieve the incorporation of s.21th new exigencies to the Architecture program in ETSAV_UPC, in association with appropriate educational technical skills into the training of future architects to these new challenges. ToSCA team focused, in particular, on following challenges: education for innovation, collaborative work in multidisciplinary working teams, the importance of communication skills, and promoting students self-learning. Zamora (2014).

The ToSCA team had two main starting hypotheses. Firstly, that to add a real client on the known problem-solving educational methodologies, increases the stimulus on constructive learning and work. Secondly, that it will be natural and appropriate to apply cooperative learning principles into ToSCA workshop, since cooperative work among different profiles was a successful tool in Technic PDI process. Ulrich \& Eppinger (2014).

In order to achieve its goals ToSCA ETSAV_UPC is structured within a framework schedule, based on PDI Step Process, that infer rhythm in order to guarantee intense work during a week, and following the educational principles of collaborative work. Pujolas \& Lago (2004) This principle includes team work with inner diversity of profiles working in roles, that in ToSCA are inspired in Innovation Product values, as Novelty, Rigor, Communication and Implementary. One real Client purpose to the workshop his Innovation needing, professors act as a coach, and some external experts as lecturers in workshop, and the final an external jury, that includes the client, made the workshop final assessment. (More detail in http://www.etsav.upc.edu/assignatures/tosca)

Eleven ToSCA_ETSAV editions and one in TUM-ToSCA workshop in Technische Universität München, had been successfully held since 2007. These experiences allow us to confirm that the ToSCA program, provides students tools and confidence about their Innovative skills, show PDI as a professional issue in itself, make them recognize that the success is the team outcome, rather than individual one. The experience also confirms us that involving a real client in problem and in the evaluation results, increases the team's stimulus and create bonds between Industry and University. Zamora, (2014).

In 2017, ToSCA team, with the aim of raising in his knowledge on education for innovation, have accepted the challenge from Department of Architecture of Francisco de Paula Santander University (UFPS) in Cúcuta, Colombia: to transfer ToSCA methodology into its Deepening Course in the Architecture Program 


\section{Justification for the UFPS internationalisation proposal}

The experience of Internationalization of ToSCA_ETSAV taken to the architecture Program from the Francisco de Paula Santander University, located in Cúcuta city in Colombia is presented after the invitation made by the Colombian institution, which already knew in advance the path of the Workshop directed by Dr. Joan Lluis Zamora and its impact on the industrialized construction sector through the ToSCA methodology. The region of Norte de Santander highlighted until a few years ago as the first producer and exporter of unglazed red ceramic products at a national level, unlike the current scenario in which the marked need to diversify the supply of products and construction systems is evident of local manufacturing for its use in construction, requiring the industrial environment to assume structural changes in the productive processes. Sánchez (2004, 2008).

The growing synergy among universities, companies and the Colombian government through recent agreements has allowed to broaden the discussion about the needs of new constructive alternatives. OCyT (2012). As a result, the ceramic industry from Norte de Santander, is projected for the next 10 years, as an industrial sector highly equipped in technology, qualified human resources and national and international recognition, in the development of project initiatives and products that place it as a reference cluster for the Colombian Ceramic Industry. PEDCTI, (2014).

In this way, the theme assumed in this international version of ToSCA "Ventilated ceramic facades applied to sustainable housing", coincides with the statement made by the national housing ministry in Colombia through the National Sustainable Construction Policy and the action plan about innovation projects and technology update. MINVIVIENDA (2015). Thus, the results of this practice carry an important leap forward in a tropical region with an outdated industrial environment in terms of innovation.

UFPS proposes to carry out, under the ToSCA methodology, the last subject of the Deepening Course, which is a specialization course and a possible way in the UFPS study plan to obtain the Degree in Architecture.

\section{ToSCA UPC a Design Lab.II UFPS Cúcuta Colombia}

In order to transfer ToSCA UPC to workshop that finishes the Deepening course at UFPS, Colombia, the involved team must face how ToSCA teamwork are going to work when it moves to another continent, another culture, another society, and how compromise the shorter calendar that UFPS offered with weekly ToSCA structure, and no interfere on the innovation results. 


\begin{tabular}{|c|c|c|c|c|}
\hline \multicolumn{5}{|c|}{ Department of architecture- Francisco de Paula Santander University } \\
\hline & \multicolumn{3}{|c|}{ Cúcuta, Norte Santander, Colombia } & \\
\hline & \multicolumn{4}{|c|}{ Degree modality for the architecture and urbanism program } \\
\hline \multicolumn{5}{|c|}{ Deepening Course : "Ceramic in the architectural Project" } \\
\hline Subject & \multicolumn{4}{|c|}{ Module 7: Lab design II: "Ventilated Ceramic Facades applied to sustainable } \\
\hline \multirow[t]{3}{*}{ Dates } & May 2017 & Thursday 25 & Friday 26 & Saturday 27 \\
\hline & & 8:00-12:00 & 8:00-12:00 & $8: 00-12.00$ \\
\hline & & 14:00-18:00 & $14: 00-18: 00$ & \\
\hline \multicolumn{2}{|c|}{$\mathrm{N}^{\circ}$ participants: 32} & & & \\
\hline
\end{tabular}

\subsection{Adapting ToSCA methodology for a new context}

For the internationalization of ToSCA UPC to the UFPS Deepening Course, a management team is stablished conformed by Dr. J.L Zamora and Marta Adroer, in Barcelona and the coordination of Carmen Xiomara Díaz Fuentes in Cúcuta.

From the UFPS coordination, the committed key professional team for the development of a workshop with the ToSCA methodology is defined:

\begin{tabular}{|l|l|}
\hline Custumer & Cerámica Italia, \\
\hline Teaching staff & Carmen Xiomara Díaz Fuentes, Architecture Program and CIMAC UFPS \\
\hline Instructor & Ramon Galvis Centurión, Miguel Niño Ramirez Architecture Program UFPS \\
\hline \multirow{3}{*}{ Evaluating court } & Miguel Peñaranda Canal/ Deepening course coordinator UFPS \\
\cline { 2 - 2 } & Erika Ayala García/Architecture Department Director UFPS \\
\cline { 2 - 2 } & Jorge Sanchez Molina/ CIMAC Director UFPS \\
\cline { 2 - 2 } & Gustavo La Rotta/National leader of training at Cerámica Italia \\
\hline
\end{tabular}

In sum, the participants' team in this internationalization of the experience of education for innovation ToSCA has a high involvement of participants from the University and the Norte de Santander Region. Besides, there will be support by Marta Adroer from the ToSCA UPC team, who will act as director of the workshop and as a teaching instructor.

\subsection{Structural adaptation}

There are structural differences in the programming of Design Lab II and ToSCA UPC, so to deal with them in the design of the workshop for UFPS some specific didactic strategies will be implemented. 


\begin{tabular}{|c|c|c|}
\hline & ToSCA ETSAV UPC & Design Lab II UFPS \\
\hline Optional & $\begin{array}{l}\text { Optional workshop for grade } \\
\text { architecture students }\end{array}$ & $\begin{array}{l}\text { Module into an optional Deepening } \\
\text { Course "the ceramics in the architectural } \\
\text { project" }\end{array}$ \\
\hline \multirow[t]{2}{*}{$\begin{array}{l}\text { Students } \\
\text { Profile }\end{array}$} & $\begin{array}{l}\text { Students between } 7 \text { tht and 10tht } \\
\text { fourth month grade period. }\end{array}$ & $\begin{array}{l}\text { Students for obtaining the Degree or that } \\
\text { are already graduated }\end{array}$ \\
\hline & $\begin{array}{l}\text { Students aren't specific } \\
\text { knowledge on the subject of } \\
\text { innovation }\end{array}$ & $\begin{array}{l}\text { Specific knowledge on ceramics as } \\
\text { building material from the entire course. }\end{array}$ \\
\hline Schedule & $\begin{array}{l}\text { Intensive seven days week } \\
\text { workshop, }\end{array}$ & $\begin{array}{l}\text { Intensive tree day workshop with a } \\
\text { previous autonomous tutorized phase. }\end{array}$ \\
\hline \multirow[t]{2}{*}{ Participants } & \multicolumn{2}{|c|}{$\begin{array}{l}28 \text { students working in four participants collaborative teams with assigned } \\
\text { roles: Novelty, Rigor, Implementability and Communication. }\end{array}$} \\
\hline & $\begin{array}{l}\text { Minimum two teachers as } \\
\text { coach, not experts }\end{array}$ & $\begin{array}{l}\text { One tutor in the autonomous phase, and } \\
\text { four teachers as coach in the workshop. }\end{array}$ \\
\hline al Client & \multicolumn{2}{|c|}{$\begin{array}{l}\text { Real client that purposes the problem to resolve and he will receipt at the } \\
\text { end of workshop multiple innovative projects to solve it. }\end{array}$} \\
\hline sessm & \multicolumn{2}{|c|}{ External committee that includes the client made the final assessment. } \\
\hline
\end{tabular}

\subsection{Adaptation proposal ToSCA UPC to Design Lab II}

Firstly, the schedule differences implies some challenges about the framework that has been designed and practiced in twelve ToSCA editions.

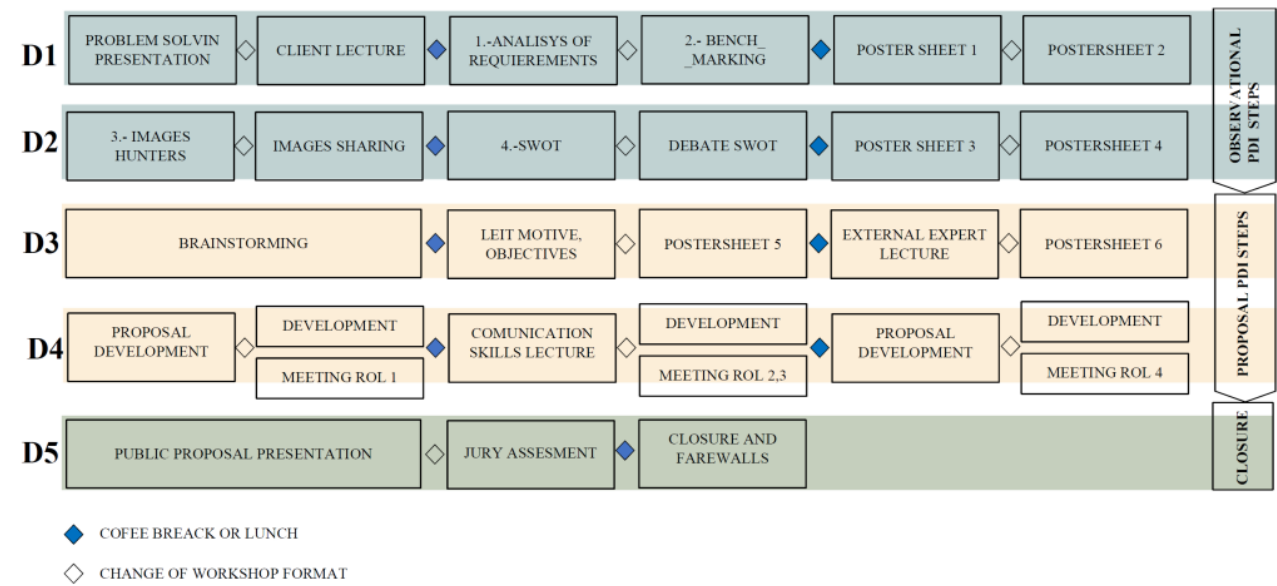

Figure 1 Schema ToSCA ETSAV UPC workshop structure.

Could the observation activities of the innovative product process be developed through autonomous tutored learning? 
ToSCA UPC team proposed to change the usual didactic format of the observation phase to an autonomous tutorized format. Therefore, is essential to provide tutorial documents to UFPS, where questions are proposed to guide participants trough the observation steps and implies also the involvement of a UFPS professor that assume the assignment of work and their supervision.

As a consequence, the adapted design framework must include workshop presentation and to debate and share the results of the autonomous work among students into proposal steps period, and it must be interesting to increase the number of teachers into Design Lab staff for better student's assistance during the shortened proposal period.

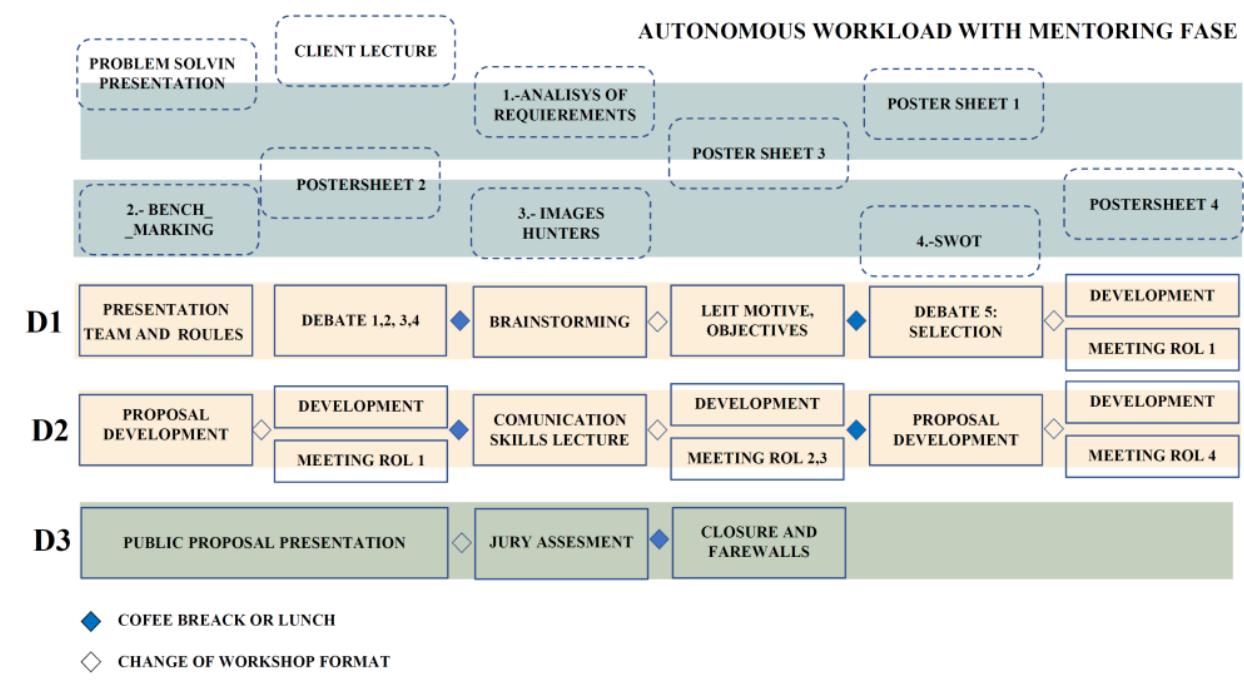

Figure 2 Schema Design Lab. II final workshop structure.

\section{Evaluation of the experience results}

The implementation of the workshop showed the importance of carrying out in detail the discussion sessions of the observation phase, at the beginning of the face-to-face activity, due its importance to elaborate, rigorously, an evaluation of innovation opportunities of the challenge raised

As a consequence of this necessary debate, all the proposed activity finally had to be concentrated in a day and a half, assuming the risk of lack of preparation time.

Some difficulties that could arise as a result of cultural differences between the UPC faculty and the UFPS students were quickly corrected by the mediation of UFPS professors itself. 
The academic result of the experience is considered very satisfactory at the discretion of the management of the UFPS Architecture Program and the customer Cerámica Italia, judging by the assessment and comments on the closure day. The assessment of the committee members was remarkable, with average team scores between 4.18 and 4.75 out of 5 .

The evaluation of the participating teachers' team was very high due to the results and the constructive interaction between the two universities.

Regarding the survey to the students allows the following data to be shown:

$100 \%$ of the participants assert that their innovation proposal was the result of teamwork, and $86 \%$ considered that it exceeded their initial expectations.

$83 \%$ of the participants considered that working with roles stimulated the homogeneous participation of all the members of the team, although only $48 \%$ considered them relevant in their product innovation proposal.

Almost $70 \%$ of the participants said that the activity of Technical Product Innovation carried out, showed them a possible professional leave-taking for architects.

$74 \%$ considered that the structure of the activity was important in the good result, but, half of them, place it only in third out of six place. In the usual ToSCA UPC surveys, this assessment is mostly placed first or second. The shortened workshop schedule may have impacted on a lower perception of the ToSCA dynamic.

The students qualify teachers as "companions" in 54\%, as "catalytic agents" in 24\%, and as "leaders" in $22 \%$, qualification of leaders, which barely appears in the ToSCA UPC surveys.

In spite of not having days between the proposition phase and the presentation of results before the jury, the presentations were all of great image quality and elaboration.

\section{Conclusion}

The specific and transversal competences acquired during the Design Lab II have been similar to those of any ToSCA ETSAV workshop, despite the socio-cultural change that internationalization entails and in spite of the modifications in the structure of the subject.

Therefore, we conclude that this experience of ToSCA Education for Innovation, within a framework of higher technical studies, achieved to motivate in a different socio-cultural environment and that is quite possible to approach the observation phase of the workshop under a self-managed tutored format, but then certain conditions are necessary. In particular: 
The coordination for the workshop adaptation, as well as the observation phase in autonomous tutored format, should be carried out by local teaching staff of the University where the activity takes place, in order to answer the doubts and stimulate the students in front of to the uncertainty that implies starting an unknown teaching experience, directed from another university and in the absence of any representative of it.

For the correct development of the proposal phase, it is necessary to add to the framework one or two activities to share and debate among students the results of the autonomous observation phase, in order to establish links between these two stages.

It seems essential for the correct international transfer of the Innovation Product Design ToSCA workshop, the local teacher's active involvement, for their exhaustive knowledge of the physical, economic and socio-cultural conditions of the place, and in proportion to the duration of the face-to-face activity in order to give personal assistance to the student teams, equivalent to that of a four-day intensive workshop.

These two factors seams induce some devaluation of students own perception of autonomy of learning and leadership.

It should be noticed that on this case, the Design Lab II module was integrated into a semester course of deepening in architectural ceramics. In addition, the higher-level student profile participants. These two facts can generate some distortion in our assessment of the results from the Workshop the observation phase as an autonomous supervised activity and on the high level of results despite the schedule difficulties.

Finally, the internalisation experience shows that it is a great opportunity to verify and improve our understanding of one of the high school 21th century challenge: education for innovation.

\section{References}

Zamora, J.L. (2014) ToSCA, a workshop on architectural building solutions: changing the way building product innovation is taught. JIDA'14: Jornadas sobre Innovación Docente en Arquitectura. Stracted04/02/2018 https://upcommons.upc.edu/bitstream/handle/209 9/14592/16_Zamora.pdf?sequence=8\&isAllowed=y

Ulrich, K.T. and Eppinger, S.D., (2012). Product design and development. 5th ed. NewYork: McGraw Hill.

Pujolàs, P. \& Lago, J.R. (coords.) (2011). El programa CA/AC ("Cooperar para aprender / aprender a cooperar") para enseñar a aprender en equipo. Implementación del aprendizaje cooperativo en el aula. Barcelona: Universitat Central de Catalunya. Stracted 04/02/2018 from: www.elizalde.eus/wpcontent/uploads/izapideak/CAACprograma.pdf 
Sánchez, J. (2004). Diagnóstico de la situación de los artesanos de la arcilla del área metropolitana de Cúcuta. Grupo GITEC. Universidad Francisco de Paula Santander.

Sánchez, J. (2008). Conformación e implementación del clúster de la cerámica de Norte de Santander. Grupo de investigación en tecnología cerámica. Editorial Universidad Francisco de Paula Santander.

OCyT (2012): Indicadores de Ciencia y Tecnología. Observatorio Colombiano de Ciencia y Tecnología.

PEDCTI, 2014-2024. Plan estratégico departamental de ciencia, tecnología e innovación. Gobernación de Norte de Santander, Colciencias. 5.6. Plan de acción clúster industria cerámica en Norte de Santander, pg-1468.

Ministerio de Vivienda, Republica de Colombia. Plan de Acción Sectorial de Mitigación. Stracted 30/01/2018 http://www.minvivienda.gov.co/Cambio\%20climatico/Presentaci ón\%20Desarrollo\%20Territorial\%20y\%20Vivienda.pdf 